\title{
The acute effect of oestrogen injection on plasma LH in freemartin heifers
}

\author{
N. Saba, A. M. Symons*, N. F. Cunningham and C. D. Boarer \\ Central Veterinary Laboratory, Ministry of Agriculture, Fisheries \& Food, \\ Weybridge, Surrey, U.K.
}

\begin{abstract}
Summary. The acute effects on plasma LH concentrations of an injection of oestradiol$17 \beta$ were studied in 7 non-cyclic heifers and 19 freemartins. One freemartin showed a normal LH surge due to the positive feedback effect of oestrogen on the hypothalamus. Of the other 18 freemartins, 4 showed positive increases in plasma $\mathrm{LH}$ and 6 were unclassified. There was no correlation between the degree of chimaerism and responsiveness to oestrogen. The results also showed that injected oestradiol suppressed the spontaneous fluctuations of plasma LH.
\end{abstract}

\section{Introduction}

Several studies have shown that an injection of oestrogen in cyclic and anoestrous ewes can result within 8-12 hr in a surge of gonadotrophins (Goding et al., 1969; Bolt, Kelley \& Hawk, 1971; Beck \& Reeves, 1972, 1973; Symons, Cunningham \& Saba, 1973). This positive feedback action of oestrogen, which has also been shown to occur in the cow (Hobson \& Hansel, 1972; Short, Howland, Randel, Christensen \& Bellows, 1973; Hobson, 1973; Martin, Koligian, Ford \& Stormshak, 1974), is either absent in the male or requires higher doses of oestrogen to be activated (Karsch, Dierschke \& Knobil, 1973). The difference in response between the male and female hypothalamus to oestrogen injection raises interesting questions in relation to freemartin heifers, a condition in which a wide spectrum of gonadal variation is encountered ranging from partly developed female to overt masculinization (Marcum, 1974). This paper presents data on the response of normal non-cyclic and freemartin heifers to oestradiol injection.

\section{Materials and Methods}

\section{Experimental animals}

Normal non-cyclic heifers. Seven Friesian heifers, 8-9 months old, were housed indoors and their plasma progesterone levels monitored over a period of 2 weeks to ensure that they were non-cyclic. The heifers were then injected i.m. with a fine suspension of oestradiol- $17 \beta$ in isotonic saline; three received $250 \mu \mathrm{g}$ in $1 \mathrm{ml}$ and four received $500 \mu \mathrm{g}$ in $2 \mathrm{ml}$. Blood samples were taken from the jugular vein into heparinized tubes just before and at $0 \cdot 5,1,1 \cdot 5,3$ and every $3 \mathrm{hr}$ thereafter for $48 \mathrm{hr}$ after the oestradiol injection.

Freemartins. Nineteen Friesian heifers, 13-15 months old, were identified as freemartins after clinical examination. The clinical observations on 6 of these animals (FM 591, FM 593, FM 607, FM 613, FM 630 and FM 693) have been described (Saba, Cunningham \& Millar, 1975), and 12 of the remaining 13 heifers were very similar. The thirteenth heifer (FM 598) differed from the other freemartins in that there was some development of the uterine cervix and horns, and the ovaries were easily palpable; these were not, however, as fully developed as in a normal heifer of the same age (P. G. Millar, personal communication). Only two of these heifers, FM 598 and FM 607, came into oestrus before the start of the experiments; they remained standing when mounted (J. F. Michel, personal

* Present address: Department of Biochemistry, University of Surrey, Guildford, Surrey, U.K. 
communication). Cytogenetic studies showed the following proportions of XY cells in the blood: FM 584, 26.1\%; FM 588, 21.5\%; FM 589, 96\%; FM 591, 60\%; FM 593, 30.5\%; FM 598, 2.4\%; FM 607, 81.7\%; FM 611, 78.9\%; FM 613, 80.6\%; FM 628, 14\%; FM 629, $25 \%$; FM 630, 2.2\%; FM 631, 58\%; FM 641, 13.1\%; FM 642, 61.1\%; FM 646, 60.8\% FM 648, 84.6\%; FM 688, 78\%; FM 693, 6.9\% (Pollock, 1973).

Trial 1. Ten freemartins housed indoors were injected $\mathrm{i} . \mathrm{m}$. with a fine suspension of $500 \mu \mathrm{g}$ oestradiol-17 $\beta$ in $2 \mathrm{ml}$ isotonic saline. Jugular vein blood samples were withdrawn into heparinized tubes just before oestrogen injection and thereafter at 2-hourly intervals for $24 \mathrm{hr}$ with a final sample at $43 \mathrm{hr}$ after oestradiol injection.

Trial 2. This was carried out 12 days after Trial 1. Four freemartins used in the first trial were injected with $2 \mathrm{ml}$ isotonic saline and the 9 freemartins not used in Trial 1 were injected with $500 \mu \mathrm{g}$ oestradiol-17 $\beta$ in $2 \mathrm{ml}$ isotonic saline. The blood sampling schedule was similar to that in Trial 1 except that 2-hourly samples were taken for $48 \mathrm{hr}$ after injection.

Blood plasma was stored at $-20^{\circ} \mathrm{C}$ until required for hormone assay.

\section{Radioimmunoassays}

Plasma LH was determined as previously described (Symons, Cunningham \& Saba, 1973) with the modification that the ${ }^{125} \mathrm{I}$-labelled $\mathrm{LH}$ and $\mathrm{LH}$ standards were set up in fetal calf serum instead of horse serum.

Oestradiol-17 $\beta$ was determined by the charcoal-gelatine disk method (Saba, 1976).

\section{Results and Discussion}

\section{Control heifers}

The plasma LH and oestradiol concentrations of the 7 non-cyclic normal heifers are presented in Text-fig. 1(a), and it is evident that the injection of the oestradiol as a fine suspension produced marked increases in the plasma oestrogen reaching maximum mean values of 50 and $75 \mathrm{pg} / \mathrm{ml}$ with the two doses used. By $9 \mathrm{hr}$ after injection the oestradiol levels were similar in both groups. Both doses of oestradiol induced surges in plasma $\mathrm{LH}$ to give peak values of $70-110 \mathrm{ng} / \mathrm{ml}$ between 15 and $21 \mathrm{hr}$ after the injection. It is clear from Text-fig. 1(a) that the action of oestradiol was restricted to the first $24 \mathrm{hr}$ with basal LH levels being maintained during the second $24 \mathrm{hr}$ of observation. Replotting of the data, using the time of peak LH as the reference point, shows that the LH surge lasts for about $9 \mathrm{hr}$ (Text-fig. 1b).
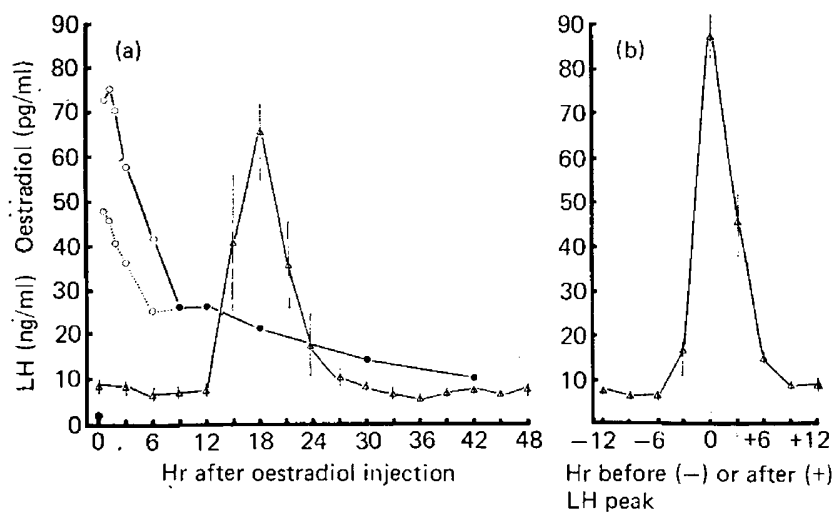

Text-fig. 1.(a) Plasma LH $(\triangle)$ and oestradiol (circles) concentrations in 7 non-cyclic 8-9-month-old normal heifers injected with $250 \mu \mathrm{g}$ ( 3 heifers, $\cdots \cdots$ ) or $500 \mu \mathrm{g}$ (4 heifers, $\longrightarrow$ ) oestradiol-17 $\beta$; $\bullet$, groups combined. (b) Mean plasma LH concentrations of the 7 heifers synchronized to the peak of the LH surge. Vertical bars represent the S.E.M. 


\section{Freemartins}

After the plasma LH assays of Trial 1 had been completed it appeared that at least 8 out of the 10 freemartins had responded to the injection of oestradiol with increases in plasma LH within $24 \mathrm{hr}$. However, the high plasma concentrations in the $43 \mathrm{hr}$ plasma samples from FM 589 and FM 613 suggested that some of the observed effects might be due to spontaneous fluctuations. For Trial 2 , therefore, 4 of the freemartins used in Trial 1 were given saline injections, the remaining 9 receiving oestradiol, and the period of observation was extended to $48 \mathrm{hr}$. Two assumptions were used to interpret the results: (i) that an effect of oestradiol on plasma $\mathrm{LH}$ would be seen within $24 \mathrm{hr}$ of oestradiol injection, and (ii) that plasma $\mathrm{LH}$ patterns $24-48 \mathrm{hr}$ after injection represented endogenous fluctuations and were not due to the oestrogen treatment. On this basis the freemartins were divided into three groups: (1) those responding with an increase in plasma LH; (2) those not responding; and (3) unclassified.

The results of Group 1 are shown in Text-fig. 2. Only 5 freemartins gave clear evidence of an oestrogen-induced increase in plasma LH. Four of the heifers showed small increases in plasma LH, those of FM 593 and FM 648 being slightly extended. The response by FM 598 (Text-fig. 2d) was very similar to that given by the control non-cyclic heifers. This was the only freemartin in this study showing some development of the uterine cervix and horns and having palpable ovaries. It is interesting that female-type freemartin sheep also give a massive and apparently normal $\mathrm{LH}$ surge after oestradiol (Short, 1974).

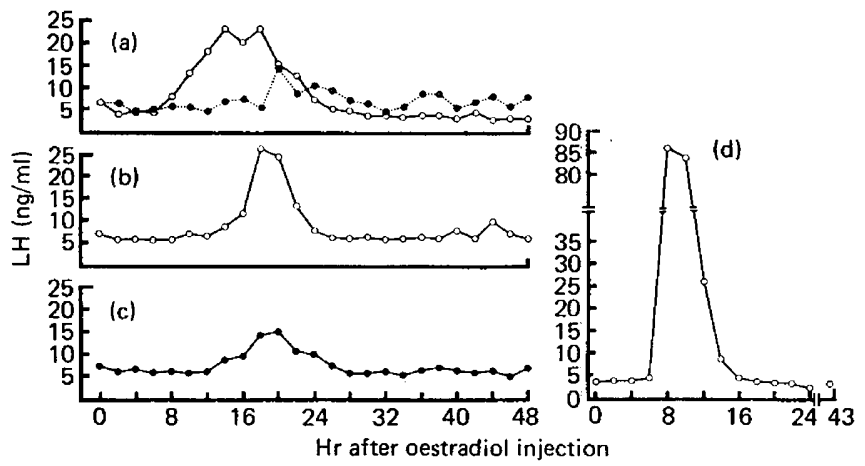

Text-fig. 2. Plasma LH concentrations of 5 freemartin heifers (Group 1, positive response) injected with $500 \mu$ g oestradiol. (a) O, FM 628; , FM 648; (b) FM 588; (c) FM 593; (d) FM 598.

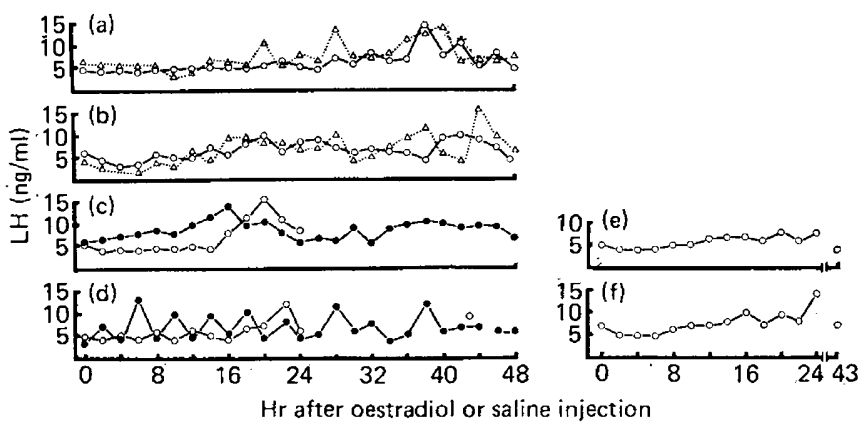

Text-fig. 3. Plasma LH concentrations of 8 freemartin heifers (Group 2, no response) injected with $500 \mu \mathrm{g}$ oestradiol or saline (2 heifers). (a) $\triangle$, FM 688; O, FM 642; (b) $\triangle$, FM 611; O, FM 641; (c) FM 646 injected with oestradiol (O), or saline (๑); (d) FM 584 injected with oestradiol (o), or saline (๑); (e) FM 607; (f) FM 591 . 


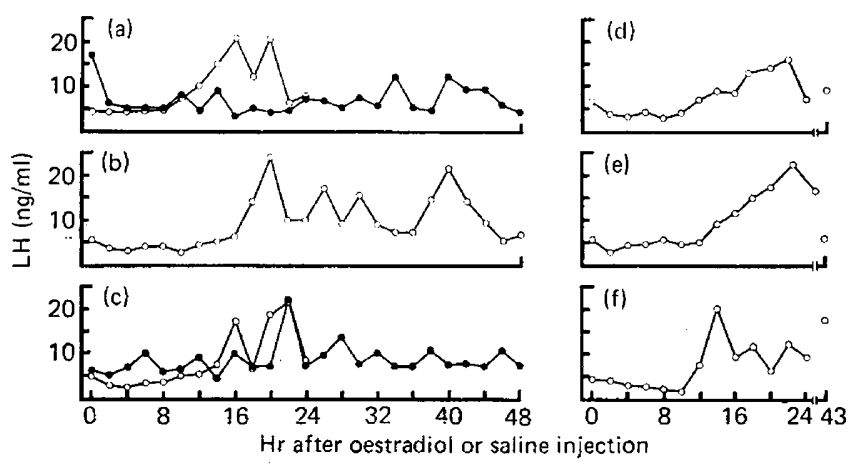

Text-fig. 4. Plasma LH concentrations of 6 freemartin heifers (Group 3, unclassified) injected with 500 $\mu \mathrm{g}$ oestradiol or saline (2 heifers). (a) FM 589 injected with oestradiol (o) or saline (๑); (b) FM 629; (c) FM 630 injected with oestradiol (o) or saline (•); (d) FM 693; (e) FM 631; (f) FM 613.

The plasma LH patterns of the 8 freemartins that did not respond to oestradiol (Group 2) are given in Text-fig. 3. The classification of FM 584 and FM 646 (Text-figs $3 \mathrm{~d}$ and 3c) was based on direct comparison of the plasma LH patterns after saline injection with those following oestradiol injection. It is clear that oestrogen did not provoke any surge in plasma LH. The other 6 freemartins in this group did not show any significant increases in plasma LH during the first $24 \mathrm{hr}$ after oestradiol injection although FM 611, 641, 642 and 688 (Text-figs 3b and 3a) showed marked fluctuations in plasma LH concentrations during the second $24 \mathrm{hr}$.

A feature well illustrated in this group of heifers was the suppression of spontaneous fluctuations in plasma $\mathbf{L H}$ concentrations for 8-12 hr after oestradiol injection. This is clearly shown by FM 584 and FM 646 for which there is a direct comparison between the plasma LH patterns after saline and oestradiol injections (Text-figs $3 \mathrm{~d}$ and $3 \mathrm{c}$ ). Comparison of the initial mean \pm S.E.M. plasma $\mathrm{LH}$ concentration $(5.36 \pm 0.27 \mathrm{ng} / \mathrm{ml})$ for the 19 freemartins with the overall mean for the period 2-8 hr after oestradiol treatment $(4 \cdot 19 \pm 0 \cdot 13 \mathrm{ng} / \mathrm{ml})$ showed that there was a significant drop in the $\mathrm{LH}$ level $(P<0.001)$ which is consistent with an inhibitory effect of oestrogen.

The results for the unclassified freemartins are shown in Text-fig. 4. The group consists of heifers in which (a) the rise in plasma $\mathbf{~ H H}$ during the first $24 \mathrm{hr}$ after oestradiol injection was at least partly explicable in terms of the spontaneous fluctuations evident during the 24-48 hr 'control' period, i.e. FM 589, FM 630, FM 613 and FM 629, or (b) there was no 'control' period and therefore insufficient evidence for an assessment, i.e. FM 631 and FM 693 in Trial 1. The apparent increase in LH level after oestradiol treatment, e.g. in FM 589 and FM 630, compared with that in the 'control' period may represent a positive $\mathrm{LH}$ surge or reflect the removal of the early inhibitory action of oestradiol.

If the two assumptions made for classifying these heifers, which are based on the response of normal cows, are not valid for freemartins then several of the animals placed in Groups 2 or 3 would have to be re-classified and placed in Group 1. Irrespective of the precision with which these freemartins have been classified, however, the evidence presented shows that only some freemartins display an LH surge after oestradiol injections. It is unlikely that plasma progesterone concentrations were responsible for differences in response to oestradiol, as at the start of the trials the plasma concentrations of this hormone were very low in 18 of the freemartins (range $0.05-0.45 \mathrm{ng} / \mathrm{ml}$ ), and in FM 628 (good positive response) it was $0.85 \mathrm{ng} / \mathrm{ml}$. There would also seem to be very little, if any, correlation between the degree of chimaerism and responsiveness to oestradiol, as the XY cell percentages were $2 \cdot 4-84 \cdot 6 \%$ for Group $1,13-81 \cdot 7 \%$ for Group 2 and $2 \cdot 2-96 \%$ for Group 3.

If the responses to oestrogen are mediated via the hypothalamus, then it would seem that these freemartins had different degrees of 'femaleness' of the hypothalamus which did not have their counterpart in either steroid endocrine function or anatomical conformation. 
We should like to thank the National Institutes of Health, U.S.A. for pituitary hormone preparations.

\section{References}

BeCK, T.W. \& ReEves, J.J. (1972) Serum LH in anestrous ewes treated with 17ß-estradiol.J. Anim. Sci.34,915.

BeCK, T.W. \& ReEves, J.J. (1973) Serum luteinizing hormone (LH) in ewes treated with various dosages of $17 \beta$-estradiol at three stages of the anestrous season. J. Anim. Sci. 36, 566-570.

Bolt, D.J., KELleX, H.E. \& HAWK, H.W. (1971) Release of LH by estradiol in cycling ewes. Biol. Reprod. 4, 35-40.

Goding, J.R., CatT, K.J., Brown, J.M., Kaltenbach, C.C., Cumming, I.A. \& Mole, B.J. (1969) Radioimmunoassay for ovine luteinizing hormone. Secretion of luteinizing hormone during estrus and following estrogen administration in the sheep. Endocrinology 85, 133-142.

Hobson, W.C. (1973) Steroid control of luteinizing hormone release in cattle. Diss. Abstr. 34B, 381382.

Hobson, W.C. \& Hansel, W. (1972) Plasma LH levels after ovariectomy, corpus luteum removal and estradiol administration in cattle. Endocrinology 91, 185-190.

KaRSCH, F.J., DIERSChKe, D.J. \& KNOBIL, E. (1973) Sexual differentiation of pituitary function: apparent difference between primates and rodents. Science, N. Y. 179, 484-486.
Marcum, J.B. (1974) The freemartin syndrome. Anim. Breed. Abstr. 42, 227-242.

Martin, S.K., Koligian, K.B., Ford, S.P. \& STORMSHAK, F. (1974) Estradiol-induced release of LH in beef heifers. Proc., West. Sectn, Am. Soc. Anim. Sci. 25, 267-268.

Pollock, D.L. (1973) A study of cytogenetics in the cattle population of Great Britain. Ph.D. thesis, Reading University.

SABA, N. (1976) Absorption of free steroids with charcoal-gelatin disks in radioimmunoassay. $J$. Endocr. 70, 141-146.

Saba, N., Cunningham, N.F. \& Millar, P.G. (1975) Plasma progesterone, androstenedione and testosterone concentrations in freemartin heifers. $J$. Reprod. Fert. 45, 37-45.

Short, R.E., Howland, B.E., RANDEl, R.D., ChristenSON, D.S. \& Bellows, R.A. (1973) Induced LH release in spayed cows. J. Anim. Sci. 37, 551-557.

SHORT, R.V. (1974) Sexual differentiation of the brain of the sheep. Colloques INSERM 32, 121-142.

Symons, A.M., Cunningham, N.F. \& SABA, N. (1973) Oestrogen-induced LH surges in the anoestrous and cyclic ewe. J. Reprod. Fert. 35, 569-571.

Received 17 April 1976 